\title{
The Myth of the Good Italian in the Italian Cinema
}

\section{Sanja Bogojević}

Faculty of Philosophy, University of Montenegro

\section{Doi:10.5901/mjss.2014.v5n16p675}

\section{Abstract}

In this paper we analyze the phenomenon called the "myth of the good Italian" in the Italian cinema, especially in the first three decades of after-war period. Thanks to the recent success of films such as Tarantino's Inglorious Basterds or Academy Awardwinning Benigni's film La vita è bella and Spielberg's Schindler's List it is commonly believed that the Holocaust is a very frequent and popular theme. Nevertheless, this statement is only partly true, especially when it comes to Italian cinema. Soon after the atrocities of the WWII Italian cinema became one of the most prominent and influential thanks to its national film movement, neorealism, characterized by stories set amongst the poor and famished postwar Italy, celebrating the fight for freedom under the banners of Resistance and representing a nation opposed to the Fascist and Nazi regime. Interestingly, these films, in spite of their very important social engagement, didn't even mention the Holocaust or its victims and it wasn't until the 1960's that Italian cinema focused on representing and telling this horrific stories. Nevertheless, these films represented Italians as innocent and incapable of committing cruel acts. The responsibility is usually transferred to the Germans as typically cold and sadistic, absolving Italians of their individual and national guilt.

Keywords: Italian post-war cinema, Holocaust, good Italians, myth

Cinematography has always been believed to be strong enough and to have enough audacity to confront the dark and horrid parts of our history. Considering the international success of recent movies, such as Tarantino's Inglorious Basterds or Benigni's Academy Award-winning film La vita è bella or Spielberg's Schindler's List, it is commonly believed that the Holocaust is a frequent and popular theme.

Nevertheless, this statement is only partly true, especially when it comes to Italian cinema which has proved to be very shy and hesitating in depicting the Holocaust and war atrocities. It should come as no surprise, given that cinema, apart from being an art, is also an industry, and a topic as sensitive as this one makes the filmmakers' job even more difficult.

Soon after the end of the WWII Italian cinema became one of the most prominent and influential ones, thanks to its national film movement, neo-realism. The films made in the period from 1945 to 1953 were mostly dedicated to the topic of the war, the fight against the fascists and Nazis, celebrating the partisans and the Resistance in Italy, but they also considered postwar social and economic problems, such as poverty and unemployment. This period, also known as the Golden Age of Italian cinema, celebrated the works of Roberto Rossellini, Vittorio de Sica and Luchino Visconti.

Interestingly, in spite of their very important social engagement, films made in this period "neglected" the topic of anti-Semitism and the faith of the Jews under the Nazi occupation of Italy. One of the earliest and most famous movies of neo-realism, Rossellini's Rome, Open City, completely fails to mention the deportation of more than 1,000 Jews from the Rome ghetto on $16^{\text {th }}$ October 1943. It would take almost 20 years for Carlo Lizzani to make a film called L' Oro di Roma (Rome's Gold) about this horrible and shameful part of Italian history.

This silence was not only present in Italian cinema, but it was also persistent in literature and in publishing circles. The most famous example is that of Primo Levi. After his return from Auschwitz, Primo Levi wrote an autobiographical novel If This Is a Man (Survival in Auschwitz), a testimony of his incarceration in the Auschwitz concentration camp from February 1944 until January $27^{\text {th }} 1945$. The first manuscript was completed in 1946 but was soon rejected by Einaudi, an important publisher from Turin, famous for its anti-fascist social commitment. The manuscript was rejected by a wellknown Jewish author, Natalia Ginzburg, who was editor at the time, because it did not fit with the house's editorial plans. The book was eventually released in 1947 by the small publisher De Silva with a print run of 2,500 and accepted for publication by Einaudi only eleven years later. Nonetheless, Ginzburg wrote the introduction to The Diary of Anne Frank published in Italy in 1954 by the same publisher which had rejected Levi's book (Perra: 2010: 13).

The story of Anne Frank at that time was not seen as a testimony to the tragedy of the Holocaust, but as an insightful coming-of-age story of a young girl locked in a hidden little room, in the era of World War II (Laqueur \& Tydor Baumel: 2001: xv). The Italian public was not prepared for a story of an Italian Auschwitz returnee, and the lack of this 
topic was more a product of selective memory on a national level (Perra: 2000:13). What was consciously neglected during this period was the representation of the Holocaust as an event that also involved Italians.

The postwar period in Italy was known for two very dominant and different ideologies, a communist one and a Catholic one. The communists looked at the Jewish deportation as a political act, and this is the reason why in the first 15 years after the war there were so few films about the Holocaust. The Jews, their deportation and death, Italian antiSemitic and Racial Laws are described vaguely, rarely and if at all, always in the context of political deportation. At the same time the Roman Catholic Church had a similar attitude and remained silent for a long time. In this period, cinema was developing in "the shadow of a steeple" as Gian Piero Brunetta, a famous Italian historian, defined it (Pezzetti: 2013:15).

From the immediate postwar period, there was general consensus on the need to portray Italy as a victim country, therefore Italians could not portray themselves as aggressors and perpetrators and the stories were usually set somewhere abroad, far away from Italian territory (Perra: 2000: 218).

It comes as no surprise that one of the first and few films shot in the postwar period, which talked about the Holocaust is an anti-Semitic one. The film The Wandering Jew (L'ebreo errante) was made in 1947 by an ex-fascist director, Goffredo Alessandrini. The plot of the movie is set outside Italy, and the movie was memorable for the representations of concentration camps which were not very plausible at the time and today are almost unacceptable. The Jewish prisoners are strong and tanned and the concentration camps remind us more of a military training camp. As Marcello Pezzetti explains it, Alessandrini must have confused the concentration camps of Auschwitz with the military training camps of the Italian fascist army in Africa (Pezzetti: 2013:16). Not so unpredictable if we consider his important film commitments in Mussolini's time. The main theme of the film is redemption through sacrifice. The main character, Matteo Blumenthal, decides to return to the prison he has just escaped from and sacrifice his own life to save other prisoners. The sacrifice the main character makes is not just a physical one, but it is also a sacrifice of his Jewishness which liberates him from his 'sinful origin' (Pezzetti: 2013:15).

Another film which also adopted a Christian framework of interpretation is the 1949 Monastero di Santa Chiara by Mario Sequi. After being romantically involved with a German SS officer, Esther, a Jewish singer hides in a convent and at the end of the movie dies as an already converted Christian with Schubert's Ave Maria melody in the background. So, once again, as in the previous case, Christianity offers redemption and a 'purifying death'.

The tendency to represent the Christianization of the Jewish victim continued through the next decade in spite of a more frequent problematization of the Holocaust especially after Adolf Eichmann's arrest and trial in 1960.

In 1960 Gillo Pontecorvo made a film called Kapò, an Italian-French production filmed in Yugoslavia. A young Jewish girl Edith, is helped by a good Italian doctor to hide her Jewish identity and pose as a political prisoner herself. She starts to sell her body to German soldiers in return for food, becomes fond of another German guard, and slowly becomes kapò, the one in charge of other prisoners. Edith has a crucial role in a mass escape, but she dies at the end trying to save others.

Interestingly, there is almost no mention of Italians in these films. The ones represented on the silver screen are those helping or hiding the Jews: like the Italian camp doctor in Pontecorvo's film who provides Edith with a new nonJewish identity or Teresa, an Italian political prisoner who helps Edith in spite of her fraternization with guards or her kapò cruelty.

The fascist soldiers and their role in the terrible faith of Jewish communities in Italy is completely left out in these films. Italians are present as passive and innocent observers incapable of being a part of atrocities because of their inbuilt humanism. Even the italian territory is often absent from this films. Interestingly Pontecorvo doesn't describe the deportation in Italy but rather sets these initial scenes in Paris. The myth of good Italians (Italiani brava gente) is created by not mentioning Italians at all, especially the Italians as perpetrators.

The first movie which spoke openly about the 1938 Racial Laws and role played by native components in fascist anti-Semitism was made only in 1970 by Vittorio De Sica, The Garden of the Finzi-Contini (II giardino dei Finzi Contini), based upon Giorgio Bassani's novel of the same name. For the first time in Italian cinematography, De Sica's film offered a depiction of the Italian involvement in the persecution of Jewish people by showing the fascist soldiers arresting the members of the Finzi Contini family and taking them away from their home. The film also made a clear reference to the concentration camps introducing a character with a number tattooed on his forearm who talks about Dachau horrors and the final shot of the film, where the deserted tennis court of the Finzi-Contini family resembles very much the concentration camps (Perra: 2010: 95).

This change of pace in Italian cinematic representation of the Holocaust was influenced by the 1968 revolutionary climate. During the 70 s, Italy started slowly to confront its guilt and past involvement with the fascist regime and the persecution of the Jews in Italy. A number of films which confronted the dark parts of national history was made during 
this period, such as: Bernardo Bertolucci's Strategia del ragno (The Spider's Stratagem, 1970) or II Conformista (The Conformist, 1970), Federico Fellini's Amarcord (1973), Lina Wertmüller's Film d'amore e d'anarchia (Love and Anarchy, 1973), Pasolini's Salò (1975) or Ettore Scola's Una giornata particolare (A Special Day, 1977).

This process was yet to be intensified in the 90's especially after the changes that took place both at the global (the fall of the Berlin Wall, dissolution of the Soviet Union) and national level (the disintegration of the conservative Christian Democratic Party, which had ruled Italy for almost fifty years and the growing problem of immigrants), leaving space for "the stories of others" and for dealing with the tragic episodes of national history. This does not imply that the representation of the Italians as good and incapable of committing crimes was completely eradicated from Italian cinema. It was still a major feature of Italian mainstream cinema, and interestingly, it did offer an image of Italians loved and requested by the international film public. For example, the 1991 film Mediterraneo by Gabriele Salvatores offers an idyllic image of Italian soldiers, stranded on a Greek island, who like to sing and paint. The film, produced by Silvio Berlusconi, won the Academy Award for Best Foreign Language Film and was very popular in Italy and abroad and, as expected, neglected the role of Italians as fascist occupiers in Greece. This general attitude continued during the next few years and largely thanks to the political climate which was much focused on highlighting the important role of 'good Italians'.

As Millicent Marcus defined it, Italian cinema has become a sort of collective resonator for the tensions and political contradictions of the Italian nation (Marcus: 2007:27) and it is still to this day a work in progress.

In this paper we have tried to analyze the so- called phenomenon of the "good Italians" in the Italian cinema, especially in the first three decades of after-war period. We have shed light on unusual contradictions of Italian culture and society which created a stereotypical representation of Italians during the WWII in the Italian cinema as naive and passive observers incapable of being a part of war crimes and atrocities.

\section{References}

Laqueur, W. \& Tydor Baumel, J. (2001). The Holocaust Encyclopedia, New Haven and London: Yale University Press.

Marcus, M. (2007). Italian Film in the Shadow of Auschwitz. Toronto: University of Toronto Press.

Pezzetti, M. (2013). II cinema della Shoah negli anni del grande silenzio (1945-1970). In Minuz, A. \& Vitiello, G. (Ed.), La Shoah nel cinema italiano (pp. 7-32). Soveria Mannelli: Rubbettino.

Perra, E. (2010). Conflicts of Memory. The Reception of Holocaust Films and TV Programmes in Italy, 1945 to the Present, Bern: Peter Lang AG- International Academic Publishers.

\section{Filmography}

L'ebreo errante (Alessandro Gofreddi, 1947)

II monastero di Santa Chiara (Mario Sequi, 1949)

Kapò (Gillo Pontecorvo, 1960)

Il giardino dei Finzi Contini (Vittorio De Sica, 1970)

Mediterraneo (Gabriele Salvatores, 1991) 